\title{
Kıbrıs'ta Modern Belediye Teşkilatının Doğuşu (1868-1876)
}

\author{
Mehmet Demiryürek* $^{*}$
}

\section{$\ddot{O ̈}_{z}$}

1850'lere kadar Osmanlı İmparatorluğu'ndaki beledî işler Kadı, Muhtesip ve İhtisap Ağası gibi yerel yetkililer tarafindan yerine getirildi. Belediye terimi Tanzimat döneminde ortaya çıtı ve günümüzdeki anlamını kazandı. 1857 yllında Altıncı Daire-i

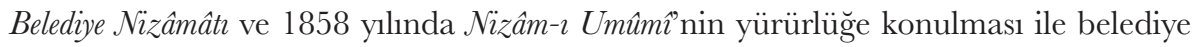
teşkilatı meydana getirmek için ilk adım imparatorluğun başkentinde atıldı ve Galata ve Beyoğlu Belediyesi kuruldu. 1867 yllı Vilayâtta Devâir-i Belediye Meclislerinin Vezâif-i Umûmiyyesi Hakknda Talimat adlı yeni bir nizamnameye tanık oldu ve bu düzenleme Osmanlı eyaletlerinde belediye teşkilatının vücut bulmasını beraberinde getirdi. Kıbrıs Tanzimat döneminde modern belediyelerin teşekkül ettiği ilk yerlerden biriydi. Şu halde bu çalışmanın amacı ilk belediyelerin Kıbrıs'ta nasıl ve ne zaman kurulduğunu ortaya koymak ve Tanzimat dönemi çalışmaları ile Osmanlı Imparatorluğu'ndaki belediyeler tarihine katkıda bulunmaktır.

Anahtar Kelimeler: Osmanlı İmparatorluğu'nda Belediyeler, Yerel yönetim, Tanzimat, Modernleşme.

\section{The Emergency of the Modern Municipality Organization in Cyprus (1868-1876)}

\begin{abstract}
Up to 1850 s the municipal works in the Ottoman Empire were carried out by the local afficials, such as Kadı, Muhtesip and Ihtisap Ağası. The municipality term occurred in the Tanzimat period and gained its modern meaning in present-day. The first step was taken to establish a municipality organization in the capital of the Empire, by making a by-laws called Altıncı Daire-i Belediye Nizamâtı in 1857 and Nizâm-ı

* Prof. Dr., Hitit Üniversitesi, Fen Edebiyat Fakültesi, Tarih Bölümü, Çorum/TÜRKIYE, mehmetdmryrk@gmail.com ORCID: 0000-0003-3506-5421 DOI: 10.37879/belleten.2020.1115

Makale Gönderim Tarihi: 22.02.2019 - Makale Kabul Tarihi: 02.10.2019
\end{abstract}


Umûmi in 1858, and the municipality of Galata and Beyoğlu was set up. The year 1867 witnessed a new by-law entitled Vilayâtta Devâir-i Belediye Meclislerinin Vezâif- $i$ Umûmiyyesi Hakkinda Talimat and this regulation brought about the establishment of the municipal organization in the Ottoman provinces. Cyprus was one of the first places where the modern municipalities were founded during the Tanzimat period after above mentioned regulations. Then, this research seeks to reveal when and how the first municipalities were formed in Cyprus and to contribute to the studies related to Tanzimat period and the history of the municipalities in the Ottoman Empire.

Keywords: Municipalities in the Ottoman Empire, Local Administration, Tanzimat, Modernization.

\section{Giriş}

XIX. yüzyıl ortalarına kadar günümüzde belediyeler tarafindan gerçekleştirilen temel hizmetler "hükümet temsilcisi yöneticiler, esnaf dernekleri temsilcileri, kadılar ve kent ileri gelenlerince karşılanmakta idi." Kırım Savaşı sırasında İstanbul'un içinde bulunduğu durum ${ }^{2}$ ve yabancı uzman ve yöneticilerin artan talebi üzerine 1854 yılında İhtisap Nezareti kaldırılarak Şehremaneti kuruldu, ama bu teşkilat istenilen başarıyı sağlayamadı. ${ }^{3} \mathrm{Bu}$ nedenle 1857 yılında yeni bir yapılanmaya gidildi ve İstanbul'un 16 belediye dairesine ayrılması kararlaştırılarak önemine binaen uygulamaya Altıncı Belediye Dairesi olarak adlandırılan Beyoğlu-Galata çevresinde başlandı. 11 Cemaziyelahir 1274 (28 Aralı 1857) tarihinde Altnc Daire-i Belediye Nizamâtı ve 24 Şevval 1274 (7 Haziran 1858) tarihinde de Devâir-i Belediyeden Al-

1 Musa Çadırcı, Tanzimat Döneminde Anadolu Kentlerinin Sosyal ve Ekonomik Yapısı, Türk Tarih Kurumu Basimevi, Ankara 1997, s. 273.

2 "Bu savaş sirasinda birçok zengin Avrupal İstanbul'a (Galata, Pera) yerleşti ve Avrupaî tarzda binalar inşa ettiler. Artan ticarî faaliyetler, özellikle şehrin bu iki bölïmünde, belediye hizmetlerinin oluşturulmast ihtiyacına işaret ediyordu." George A. Dionyssiou, The Implementation of the Tanzimat Reforms in Cyprus (1839-1878), MAM (The House of Cyprus \& Cypriologial Publications), Nicosia 2009, s. 147-148. Ayrica bk. Mehmet Seyitdanlıŏglu, Tanzimat Döneminde Modern Belediyeciliğin Doğuşu, Türkiye İş Bankası Kültür Yayınları, İstanbul 2010, s. 3-4.

3 Çadırcı, Tanzimat Döneminde Anadolu Kentlerinin Sosyal ve Ekonomik Yapısı, s. 273-274; Tarkan Oktay, "Osmanlı Döneminde Modern Belediye Kurumunun Doğuşu ve Gelişimi”, (Eds) Erol Özvar ve Arif Bilgin, Selçukludan Cumhuriyete Şehir Yönetimi, Türk Dünyası Belediyeler Birliği Yayını, İstanbul 2008, s. 385.

4 Bu nizamât, 18 Cemaziyelahir 1285 (6 Ekim 1868) tarihli "Dersaadette İdare-i Belediye Nizamnamesi" ile "tadil ve ikmal" edilmiştir. Bk. Düstur, Cüz-i sâni, Matbaa-i Amirede Tab“ Olunmuştur, Sene 1289, s. 450-459. 


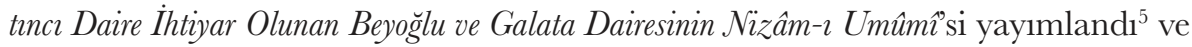
uygulanmaya başland.

1864 Vilayet-i Umumiye Nizamnamesi belediyeden de bahsetmektedir. ${ }^{6}$ Ortaylı'ya göre "Osmanl taşra şehirlerinde modern beledî teşkilatlanmaya" 1864 Vilayet Nizamnamesi ile başlandı, fakat başarılı bir uygulama gerçekleştirilemedi. ${ }^{7}$ İstanbul d1şındaki yerlerde belediye teşkilatının kurulması amacıyla ayrıntılı talimat ancak 22 Rebiülevvel 1284 (4 Temmuz 1867) tarihinde Vilayâtta Devâir-i Belediye Meclislerinin Vezâif-i Umumiyyesi Hakkında Talimat adıyla hazırlandı. ${ }^{8} 16$ bentten oluşan talimata göre, belediyeler binalardan, kaldırımlardan, bütçe hazırlanmasından, çöp arabalarından, itfaiye teşkilatından, temizlikten, kimsesizlerin bakımından, ekmekçi, bakkal ve kasapların denetiminden, başıboş hayvanların toplanmasından, dilencilerin kontrolünden, yolların açık bulundurulmasından, eğlence yerleri ile çarşı ve pazarların denetiminden ve narh ile ölçülerden sorumlu olacaktı. Talimata uygun olarak 1868'de İzmir'de, 1869'da Selanik'te ${ }^{9}$ ve yine 1869 'da Bağdat'ta ${ }^{10}$ belediye teşkilatı kuruldu. 1871 yılında çıkarılan Vilayet Nizamnamesi belediyelerle ilgili olarak özel bir bölüm içermesine ${ }^{11}$ rağmen 1876 yılında I. Meşrutiyet ilan edildiğinde belediye kurumu Anadolu kentlerinde yeterince etkin değildi. ${ }^{12}$ Tarkan Oktay, 1854-1876 yılları arasındaki dönemi "beledî uygulama” ve "kurumsal gelişim"

5 “Altıncı Daire-i Belediye Nizamâtı", Düstur, Cüz-i sâni, Matbaa-i Amirede Tab` Olunmuştur, Sene 1289, s. 460-463; "Devâir-i Belediyeden Altıncı Daire İhtiyar Olunan Beyoğlu ve Galata Dairesi’nin Nizâm-ı Umumîsi”, Düstur, Cüz-i sâni, Matbaa-i Amirede Tab‘ Olunmuştur, Sene 1289, s. 464-490. Düsturun bu cildinde yayımlanan Devâir-i Belediyeden Altıncı Daire İhtiyar Olunan Beyoğlu ve Galata Dairesi'nin Nizâm-1 Umumîsi”nin sonunda tarih yoktur. Ancak aynı Nizam-1 Umumi'nin Düstur'un 1282 tarihli baskısında (s. 214-230) yer alan metninin sonunda 24 Şevval 127487 Haziran 1858) tarihi bulunmaktadır. Bk. Düstur, Defa-i Saniye Olarak Matbaa-i Amirede Tab‘ ve Temsil Kılınmıştır. Fi gurre-i Zilhicce sene 1282.

6 "Vilayet Nizamnamesi", Düstur, Matbaa-i Amirede basılmıştır. Sene 1289, s. 608. "Dördüncü Madde: Her kaza kurâya münkasım olub her karyede aşă̆ bendlerde beyan olunan veçhile bir idare-i beledî olacaktır."

7 Ilber Ortaylı, "Belediye", Türkiye Diyanet Vakfi Islam Ansiklopedisi, C 5, Türkiye Diyanet Vakfi Yayınları, İstanbul 1992, s. 400.

8 Düstur'un içindekiler bölümünde bu isimle verilen Talimat, Talimatın bulunduğu sayfada "Daire-i Belediye Meclisinin Vezâif-i Umûmiyesi Hakkında Talimat” adıyla yer almıştır. Bk. Düstur, Cüz-i Sâni, 1289, s. 493-497. Talimat’ın günümüz harfleriyle yayını için bk. Mehmet Seyitdanlığlu, Tanzimat Döneminde Modern Belediveciliğin Doğuşu, s. 204-207.

9 Tarkan Oktay, Selçukludan Cumhuriyete Şehir Yönetimi, s. 394-95.

10 İber Ortayl, Türkiye Teşkilat ve İdare Tarihi, Cedit Neşriyat, Ankara 2012, s. 436.

11 "İdare-i Umûmiye-i Vilayât Nizamnamesi”, Düstur, Matbaa-i Amirede Tab' Olunmuştur, 1289, s. 625-651. Tarkan Oktay, Selçukludan Cumhuriyete Şehir Yönetimi, s. 396.

12 Çadırcı, Tanzimat Döneminde Anadolu Kentlerinin Sosyal ve Ekonomik Yapısı, s. 273-274. 
bakımından Türkiye'de modern belediyeciliğin "kuruluş" dönemi olarak adlandırmaktadır. ${ }^{13}$ İkinci dönemin başladığı 1877 yılında, her ikisi de 27 Ramazan 1294 (5 Ekim 1877) tarihli olan Dersaadet Belediye Kanunu ile Vilayât Belediye Kanunu çıkanld. . ${ }^{14}$ Oktay'ın "sınırlı gelişme” olarak adlandırdığı ikinci dönemin (18771908) başlarında Kıbrıs'ta çok önemli bir gelişme yaşandı. Çünkü Kıbrıs'ın idaresi Temmuz 1878'de İngiltere'ye devredildi. Ada hukuken Osmanlı toprağı sayılsa da idari, sosyal ve kültürel olarak farklı bir mecraya girmişti ve dolayısıyla Kıbrıs'ta modern belediyecilik konusunda farklı bir oluşum yaşanmaya başlamıştır.

Osmanlı İmparatorluğu'nun diğer yerlerinde olduğu gibi Kıbrıs'ta da belediye teşkilatı Tanzimat döneminde kurulmuştur. Bununla birlikte bu teşkilatın ilk kez hangi şehirde ve nasıl kurulduğu sorusu aydınlığa kavuşturulamamıştır. İlber Ortaylı, kaynak göstermeden ve genel olarak 1871'de Kıbrıs'ta belediye idaresinin kurulmuş olduğunu yazmaktadır. ${ }^{15}$ Bu konuda en kapsamlı çalışma Hasan Samani'ye ait olup gerek doktora tezinde ${ }^{16}$ gerekse yeni yayımladığı bir çalışmasında ${ }^{17}$ konuyu ele almıştır. Samani, doktora tezinde, İngiliz tarihçi George Hill'e dayanarak "1856 ynlında Lefkoşa ile diğer önemli kazalarda Belediye Meclisleri kurulmuştu. (...) Lefkoşa Belediye Meclisi'nin bir Müslüman başkan ve üçü Müslüman, üçü de gayrimüslim olmak üzere alt üyesi vard. Diğer büyük kazalarda da birer belediye meclisi oluşturulmustu. Bu meclislerin üye sayıs ikisi Müslüman, ikisi de gayrimüslim olmak üzere dörttiü. Belediye Meclisleri temizlik, sağhlk, yol ve şehir planlaması, inşaatlarn denetlenmesi gibi hizmetleri yerine getiriyorlarde" 18 diye yazmakta ise de yeni çalışmasında Hill'in yazdıklarını "muhtemelen 1856'da Kibrns'ta kurulan sancak meclisi ile kaza idare meclislerini, belediye meclisleri olarak değerlendir-

Diğer iki dönem ise 1877-1908 yıllarını kapsayan "Sınırlı Gelişme" dönemi ile 1908-1922 yılları arasını kapsayan "Kurumsallaşma" dönemidir. Bk., Tarkan Oktay, Selçukludan Cumhuriyete Şehir Yönetimi, s. 377-378.

Bk., Düstur, Cüz-i Rabi', İstanbul 1299, s. 520-553.

Ilber Ortayll, Türkiye Teşkilat ve İdare Tarihi, s. 436. Ronald C. Jennings'in "Lefkoşa'da belediye 1884'te kuruldu" şeklindeki düşüncesi doğru değildir. Bk. Ronald. C. Jennings, "Lefkoşa", Kubrus, (Derleme ve Çeviri: Mehmet Akif Erdoğru), Galeri Kültür Yayınları, Lefkoşa 2010, s. 140.

16 Hasan Samani, Tanzimat Devrinde Kibrns (1839-1876), Hacettepe Üniversitesi Sosyal Bilimler Enstitüsü, (Yayımlanmamış Doktora Tezi), Ankara 2006.

17 Hasan Samani, “Tanzimat Döneminde Kıbrıs’ta Modern Belediyeciliğin Başlangıcı ve Lefkoşa Belediyesi", Belleten, 82/294 (2018), s. 588-626.

18 Samani, Tanzimat Devrinde Kibrus (1839-1876), s.54. Samani ayrıca "19. Tüzynlın ikinci yarnsına gelindiğinde, Kibris'n Osmanh Taşra Belediye örgütlenmesinde istisnalar arasinda olduğu ve henüz Osmanl taşrasinda belediye idarelerinin kurulmasm öngören genel bir mevzuat hazvrlanmadan önce, Kibrn'ta geleneksel kurumlarn dışında ayn belediye idarelerinin kurulduğu anlaşılmaktadrr." şeklinde bir yorumda bulunmaktadır. 
miştir" ${ }^{\prime 19}$ demektedir ki, bu görüşüne ben de katılıyorum. Sonuç olarak 1856 yılındaki durum belediyelerle ilgili değildir. Ayrıca Hill'in bu konuda kullandığı Rumca iki kaynak bulunmaktadır. ${ }^{20}$ Ancak bu kaynaklardan Sakellarios'un eserinde kullanılan ve Kıbrıs'ta (Lefkoşa ve diğer kazalarda) belediyelerin kurulmasını ifade eden tarih "1856" değil, "1856'dan sonra" şeklindedir. Kypriaka Hronika adlı eser ise Kıbrıs'ın Larnaka şehrinde belediye kurulmasılla ilgili 1858 ve 1859 yıllarına ait iki girişimden (aslında Fransız konsolosunun önerileri) bahsetmektedir. Ama bu girişimin sonucunda Larnaka'da modern bir belediye kurulduğuna dair açık bir ifade yoktur. Aslında Hill de kesin olarak "Kibris'ta (Lefkoşa ve diğer kazalarda) belediye teşkilatı 1856 ynlında kuruldu” diye yazmamaktadır. Kullanılan ifadeyi 1856'dan sonra diye anlamak daha makul görünmektedir. ${ }^{21}$ Konuya önemli katkılarda bulunan Samani’nin son çalışması, kendisinin de ifade ettiği üç bölümden oluşmaktadır: "Tanzimat öncesi dönemde beledî hizmetleri temsil eden İhtisab kurumu ve bunun Kibris'a yansimalarn", "Tanzimat döneminde Osmanl modern belediyeciliğinin başlangicu çerçevesinde Kibris'ta modern belediyelerin kurulus süreci" ve "1877/1878 itibaryla adanin idari merkezi konumundaki Lefkoşa'nın mevcut belediye teşkilat». ${ }^{22}$ Bizim çalışmamızın ilgilendiği konu Samani’nin çalışmasının ikinci kısmıdır. Bu kısımda kısaca değerlendirilen 1862 yılı girişimi ${ }^{23}$ bir yana bırakılırsa Samani'nin çalışması "Kıbrıs'ta ilk modern belediyeler nasıl ve ne zaman kuruldu?" sorusuna ayrıntılı cevap vermemektedir. Samani’ye göre 1871 yılına gelindiğinde Değirmenlik, Girne, Tuzla, Baf, Mağusa ve Limasol'da belediye teşkilatı kurulmuştu. ${ }^{24}$ Samani ayrıca 1871 'den adanın İngiltere idaresine bırakıldığı 1878 yılına kadar geçen dönemde Lefkoşa dışındaki

19 Samani, "Tanzimat Döneminde Kıbrıs'ta Modern Belediyeciliğin Başlangıcı ve Lefkoşa Belediyesi", s. 596 .

20 Athanasios Sakellarios, Ta Kypriaka: Htoi Geographia, Istoria kai Glossa tis Nisou Kyprou apo twn Arhai-

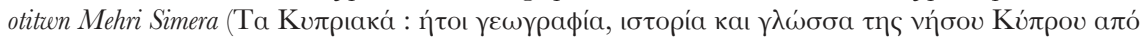

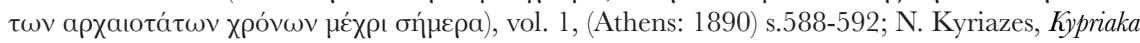
Hronika, 12 (1936), s. 208-213. (Eserlerin Rumca orijinallerinin kopyalarını bana gönderme nezaketinde bulunan Michael Michalis'e çok teşekkür ederim.)

21 "If not actually as part of the reforms of 1856, yet about the same time, municipal councils (Demarcheia) were established in Nicosia and in other chief towns", Bk. George Hill, A History of Cyprus, v. 4, Cambridge University Press, Cambridge 1952, s. 211.

22 Samani, "Tanzimat Döneminde Kıbrıs'ta Modern Belediyeciliğin Başlangıcı ve Lefkoşa Belediyesi", s. 589.

23 Samani, "Tanzimat Döneminde Kıbrıs'ta Modern Belediyeciliğin Başlangıcı ve Lefkoşa Belediyesi", s. 596-597.

24 Samani, Tanzimat Devrinde Kibris (1839-1876), s. 58-66; Samani, “Tanzimat Döneminde Kıbrıs'ta Modern Belediyeciliğin Başlangıcı ve Lefkoşa Belediyesi”, s. 600. 
kaza merkezlerinde kurulan belediyelerin "teşkilatlan hakknnda elimizdeki belgeler oldukça smorldır ${ }^{925}$ demekte ve Lefkoşa Belediyesi'nin 1877/1878 yllarına ait olan belediye defterini ayrıntılı olarak değerlendirmektedir.

Kıbrıs'ta modern belediyenin kuruluşu ile ilgili bir başka araştırma ise George A. Dionyssiou'nun doktora tezidir. ${ }^{26}$ Kitap olarak da yayımlanan bu çalışmada, İstanbul'daki ve Kıbrıs'taki belediye teşkilatı hakkında önemli bilgiler verilmekle birlikte "Kibris'ta belediyelerin kuruluşunun gerçek tarihi bilinmemektedir" şeklindeki cümle dikkat çekmektedir. ${ }^{27}$ Kıbrıs'ta belediye teşkilatının kurulmasını ele alan 2 eser daha bulunmaktadır. ${ }^{28}$ Kullanılan kaynakların belirtilmediği ve dipnot kullanılmayan bu çalışmalarda Lefkoşa Belediyesi hakkında bazı bilgiler verilse de metodolojik ve bilimsel açıdan söz konusu eserler çok yetersiz ve eksiktir.

Harry Luke'un eserinde, 1867 yllnda “Kibris'taki 16 kazann her biri kendi meclisine veya belediye meclisine sahipti' ${ }^{\prime 29}$ şeklinde bir cümle bulunurken Dionyssiou, 1869 yılından önce Larnaka'da, İstanbul'daki belediye uygulamalarına paralel olarak kurulmuş bir belediye meclisinin olmadığını belirtmektedir. ${ }^{30}$ Costas P. Kyrris ise 1856'dan sonraki dönemde 16 kazanın her birinde Belediye Meclisi'nin var olduğunu yazmaktadır ${ }^{31}$ ki bu çalışmada ortaya konulacağı üzere söz konusu düşünce doğru değildir. Rolandos Katsiaounis'in eserine ${ }^{32}$ gelince bu çalısmada Kıbrıs’in İngiliz idaresinde bulunduğu ilk yıllardaki gelişmelerden söz edilmekte olup Osmanlı dönemine değinilmemektedir.

İstanbul'da modern anlamda ilk belediye teşkilatının temeli 1857 yllında, Pa- 


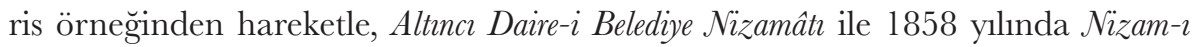
Umum $\imath$ nin yayımlanması ile atılmıştır. ${ }^{33}$ Kıbrıs söz konusu olduğunda ise bugüne kadar yapılan ve yayımlanan çalışmalar Kıbrıs'ta kurulan modern belediyelerin kuruluş tarihini tam olarak aydınlatamamıştır. Bu nedenle Kıbrıs’ta, İstanbul örneğinde, modern belediye teşkilatının ne zaman ve nasıl kurulduğu, belediyelere bırakılan gelir kaynaklarının nelerden ibaret bulunduğu ve kuruluş döneminde yaşanan sorunların neler olduğu sorularına arşiv belgelerine dayalı olarak cevaplar bulma bu çalışmanın temel amaçlarını teşkil etmektedir. Ayrıca Kıbrıs'ta belediyelerin kuruluş sürecinin tamamlandığg 1871 yılından Samani’nin değerlendirdiği 1877/1878 Lefkoşa belediye defterine kadar geçen sürede gerek başkent Lefkoşa ve gerekse diğer kaza merkezlerindeki belediyelerle ilgili kimi bilgi ve belgelere de bu çalışmada yer verilecektir.

\section{Kıbrıs'ta Modern Belediye Teşkilatının Kurulması Girişimi (1862)}

Başbakanlık Osmanlı Arşivi'nde bulunan bir belge Kıbrıs'ın merkezi Lefkoşa'da Belediye Meclisi'nden önce bir "Çarşı Meclisi”nin kurulduğundan bahsetmektedir. 13 Safer 1279 (10 Ağustos 1862) tarihli belgeye göre

"Lefkoşa şehri çarşısında füruht olunmakta bulunan enva'-i erzak ve eşyaya öteden beri şer'-i şerif ve meclis maarifetiyle ayda bir kere narh verilmekte ise de râyic-i erzak bir siyâkda olmayub vakit ve mevsime göre tedenni ve terakkî etmekte olduğundan bunun için sık sık narh verilmesi icâb etmiş olmasıyla bu mühim icrââtın ve çarşıların nezâfet ve tathîrine daimi suretde dikkat eylemek için bu kere Meclis-i Liva kararı üzerine azası İslâm ve Hristiyandan mürekkeb bir Çarşı Meclisi teşkil"

olunmuştu. Bir başka deyişle, Lefkoşa çarşısında satılmakta olan çeşitli erzak ve eşyaya mahkeme ve liva meclisi tarafindan ayda bir defa narh veriliyordu. Fakat erzakın fiyatı mevsime göre artmakta ve azalmakta olduğundan sık sık narh verilmesi ihtiyacı doğmaktaydı. Hem bu ihtiyacı gidermek hem de çarşıların temizliğiyle daimi olarak ilgilenmek amacıyla ve Liva Meclisi kararıyla Müslüman ve Hristiyan üyeden oluşan bir "Çarşı Meclisi” kurulmuştu. Belgeye göre, bu meclis " $k a ̂ f f e-i$ erzak ve eșyaya iktizasına göre onbeş günde ve bazen haftada bir kere narh verilmek ve çarşılarn

33 İlber Ortaylı, "Nizamname-i Umûmi’nin" 1858 yılında yayımlandığını yazmakta ise de (bk. İlber Ortaylı, "Belediye", s. 400), bu bilgi yanlıştır. Çünkü yayımlanan belge "Devâir-i Belediyeden Altınc Daire İhtiyar Olunan Beyoğlu ve Galata Dairesi'nin Nizâm-ı Umûmisi” adını taşımakta olup 17 Ramazan 1859 (20 Nisan 1859) tarihinde yayımlanmıştır. Bk. Düstur, Cüz-i sâni, Matbaa-i Amirede Tab‘ Olunmuştur, Sene 1289, s. 464. 
nezâfetine ve hususât-ı sairesine kemâl-i itina ve dikkatle" çalışmış ve herkesin beğenisini kazanarak "menâfi-i kesîresi müşâhhade" olunmuştu. Belge, Lefkoşa'daki "Çarşı Meclisi”"nin ne zaman kurulduğunu belirtmiyorsa da yaptığı işler nedeniyle söz konusu "Çarşı Meclisi”ni Lefkoşa'da modern belediye teşkilatının kurulmasının ilk adımı olarak değerlendirmek yerinde olacaktır. ${ }^{34}$

Belgenin devamında verilen bilgiden böyle bir meclisin Tuzla kasabasında da kurulması girişiminden bahsedilmektedir. ${ }^{35}$ Belgeye göre, Lefkoşa'daki meclis başarılı bir şekilde çalıştığı için "Tuzla iskelesinde dahi böyle bir meclisin teşkiline lüzum görünmüşs"tür. Çünkü Tuzla iskelesi

"ecnebi memurlarının ikâmetgâhı olduğundan meclis-i mezkûrun cereyan-1 tamam-1 nüfuzu için yerli ve ecnebiden muhtelit olması ve çarşıca olan memurîninden fazla turuk ve ebniyenin dahi mahsus olan nizâmı üzere tesviye ve inşâsına ve sair bu misillü ihtiyacât-ı belediyeye nezâret edip tesviyesi nakde muhtaç olan hususât-1 mühimmenin dahi sekene-i kasabadan vech-i itidâl ile cem ve istihsâl ve iktizası üzere sarf ve istimal eylemesi mülkçe fevâid-i mütenevviaya müstelzim görünmüş ve ekser memurîn-i ecnebiyenin dahi emel ve efkârı bu merkezde"

bulunmuştur. Yani Tuzla iskelesi Lefkoşa'dan farklıydı ve Lefkoşa'dakine benzer bir meclis ihtiyacı karşılamayacaktı. Yabancı konsolosluklar Tuzla iskelesindeydi ve meclisin tam olarak etkili bir şekilde çalışabilmesi için kurulacak mecliste yabancılar da bulunmalıydı. Ayrıca bu meclis sadece çarşı işleriyle değil, kasabanın yol ve bina işleriyle de ilgilenmeli, yol ve binaların bu konuda çıkarılmış yönetmelikler çerçevesinde yapılmasını sağlamalı ve diğer bu tür "ihtiyacât-ı belediye" (belediyelik ihtiyaçlar) ile ilgilenmeliydi. Bu hizmetler ise para gerektirdiğinden kasaba halkından bir miktar para/vergi toplanması söz konusu olacaktı. İşte bütün bu

Samani de haklı olarak aynı belgeyi "Osmanlı Kıbrısı'nda şekilsel de olsa modern belediyeciliğe atılan ilk adımlar"dan biri olarak değerlendirmektedir. Samani, "Tanzimat Döneminde Kıbrıs’ta Modern Belediyeciliğin Başlangıcı ve Lefkoşa Belediyesi", s. 597.

35 Söz konusu belge Samani tarafindan "Lefkoşa'daki Çarşı Meclisi'ne atıfta bulunularak meclisin bir benzerinin yabancı tüccar ve konsolosluk memurlarnnn ikamet yeri olan Tuzla'da da açılmasının yararlı olacağı belirtilmekte, mecliste yerli Hristiyan ve Müslüman üyelerin yanısıra Tuzla'da ikamet eden yabancilarn da temsiliyet talebinde bulunduklan bildirilmektedir. Tuzla'da kurulması düşünülen bu teşkilatın İstanbul için hazırlanı uygulanan Altınc Daire-i Belediye Teşkilatı'nın nizâmnâme ve talimatnamesine göre kurulabileceği aynca belirtilmektedir. Anlaşıldı̆̆ kadaryyla Kibrns idaresince merkeze sorulan ilgili talep ve düşünceler karışılı ve hoşnutsuzluğa sebep olacağından' kabul görmemiş, 'şimdilik eski uygulamaya devam edilmesi' istenmiştir" şeklinde özetlenmiştir. Bk. Samani, “Tanzimat Döneminde Kıbrıs’ta Modern Belediyeciliğin Başlangıcı ve Lefkoşa Belediyesi", s. 596-597. 
nedenlerden dolayı da kurulacak bu teşkilatın "bir kâide-i esas üzere vaz ve teşkili icâp" ettiği (sağlam bir temel üzerine kurulması lazım geldiği) için İstanbul'da "bulunan altncr daire-i belediye meclisinin teşkilinde suret-i hareketine dair nizam ve talimat yapılmıs olduğuna binaen bunun dahi ol esas üzere binası" akla geldiğinden dolayı bahsi geçen nizamname ve talimâtın bir kopyasının Kıbrıs'a gönderilmesi talep edilmiştir.

Yukarıda özetlenen belge birkaç önemli bilgi vermektedir. Bunlardan birincisi Kıbrıs'taki modern belediye teşkilatının ilk adımının "Çarşı Meclisi" adı altında Lefkoşa'da atıldığıdır. Fakat ikinci ve daha önemli bir bilgi ise Kıbrıs'ta modern belediye teşkilatı kurma girişiminin 1862 yllında Lefkoşa'dan önce Tuzla iskelesi ${ }^{36}$ (Larnaka) için düşünülmüş olmasıdır. Bu amaçla İstanbul'da Galata-Beyoğlu için 1857 yllında Paris örnek alınarak hazırlanmış olan "Altınc Daire-i Belediye Nizamnamesi" nin bir kopyasının Kıbrıs'a gönderilmesi talep edilmiştir. O halde 1862 yllından önce Kıbrıs'ta Galata-Beyoğlu örneğinde kurulmuş modern belediye teşkilatı yoktu. Üçüncü önemli bilgi ise dönemin Kıbrıs mutasarrıfi ile ilgilidir. Belgenin altındaki imza Mehmet Ziyaeddin, bilinen adıyla Ziya Paşa'ya aittir. Ziya Paşa'nın mutasarrıflığı sırasında Kıbrıs'a önemli hizmetlerde bulunduğu bilinmektedir. Bu belge göstermektedir ki, Kıbrıs'ta modern belediye teşkilatının kurulma girişiminde Ziya Paşa'nın rolü olduğu açıktır.

\section{Çarşı Meclisi'nden (1862) Daire-i Belediye Teşkilatına (1868)}

Lefkoşa'daki “Çarşı Meclisi”nin Lefkoşa Belediye Meclisi'ne kısa sürede dönüşmediği, bahsi geçen talebe verilen cevaptan anlaşılmaktadır. Kıbrıs’tan gönderilen yazı Meclis-i Vâlâ'ya havale olunmuş ve sonuçta "Eğerçi bu surette inha buyrulmuş ise de bunun orada tamamen icrâsı sudą (rahatsızhğgl) davet eder işlerden olup şimdiki halde ola geldiği üzere bu maddenin hüsn-i idaresi için cevap" şeklinde bir sonuç elde edilmiştir. ${ }^{37}$ Belgede, uygulamanın rahatsızlığa neden olacağı belirtilmekle birlikte, bu uygulamanın neden ve nasıl bir rahatsızlığa sebep olacağı konusunda maalesef açıklama yoktur. Sonuç olarak Lefkoşa'daki bu dönüşümün ve Larnaka'da belediye teşkilatı kurulmasının 1862 yllından sonra olduğu kesindir. ${ }^{38}$

36 Aslında İskele (veya Tuzla iskelesi) Tuzla'ya (Larnaka'ya) bağlı bir yerleşim yeriydi. Zamanla Larnaka ile bütünleşmiştir. Örneğin 1830-31 yllında yapılan nüfus sayımında İskele kasabası, "Kasaba-i İskele-i nefs-i Tuzla" adıyla ve ayrı olarak kaydedilmişti. Bk. BOA, TŞR.KB.d., Sıra No:40, s. 111.

37 BOA, $M V L$, Dosya No: 788, Gömlek No: 65.

3831 Temmuz 1865 tarihli bir kaylt "Lefkoşa Belediyesinden" bahsetmektedir. Kayda göre Lefkoşa'daki Aziz Efendi Tekkesi'nden yeni Belediye Çarşısı'na bir yol yapılması gündeme geldiğinde 


\section{Lefkoşa ve Tuzla Belediyeleri}

Kıbrıs Sancağı'nın merkez kazası Lefkoşa'da İstanbul örneğinde kurulan modern belediye teşkilatının 1868 yllında kurulmuş olduğunu düşünmek yanlış olmayacaktır. Lefkoşa Belediyesi'nin “Kitabet ve Sandık Emaneti” hizmetlerini yaklaşı üç yıl yürüten Mustafa Efendi, 12 Temmuz 1871 tarihinde görevinden ayrıldığında muhasebesi görülmüş, belediyeye borçlu çıkmış ve Sancak İdare Meclisi'nde sorgulanmıştır. Mustafa Efendi sorgusunda bu göreve "seksen dört senesi Mayıs ibtidasında" (1 Mayıs 1284=12 Mayıs 1868) tarihinde tayin olunduğunu ifade ${ }^{39}$ etmiştir ki, bu durum Lefkoşa Belediyesi'nin kuruluşu açısından Kıbrıs'ın diğer kazalarıyla eşzamanlılık göstermektedir. 26 Ramazan 1288 (9 Aralık 1871) tarihli bir kayda göre ise Lefkoşa Belediye Meclisi kâtibi Mahmut Efendi idi ve 125 kuruşluk maaşına 25 kuruş zam yapılması talebi Liva İdare Meclisi tarafindan uygun bulunmuştu. Kâtip Mahmut Efendi'nin maaşı 150 kuruş olacak ancak maaş zammı nedeniyle kendisine ek iş verilmeyecekti. Söz konusu zam 1 Eylül 1287 (13 Eylül 1871) tarihinden geçerli olacaktt. ${ }^{40}$ Kâtip Mahmut Efendi, Mustafa Efendi'den sonraki kâtip olmalıdır.

Dionyssiou, 1869 yılından önce Larnaka'da, İstanbul'daki belediye uygulamalarına paralel olarak kurulmuş bir belediye meclisinin olmadığını ${ }^{41}$ yazmakta ise de 1868 yılında Larnaka'da belediye teşkilatının var olduğu anlaşılmaktadır. 27 Rebiülahir 1285 (17 Ağustos 1868) tarihinde Larnaka Belediye Meclisi Başkanlığı'na Mehmet Ali Efendi tayin edilmiş ve bu arada Tuzla'da yaşayan Avrupalılardan da belediyeye üye tayin edilip edilmemesi tartışmaları yapılmıştı. ${ }^{42}$ Tuzla Belediyesi, "Tuzla ve İskele Kasabaları Daire-i Belediyesi" adıyla anılıyor ve seçilen (veya atanan) belediye çalışanları Kaza İdare Meclisi tarafindan onaylandıktan sonra Lefkoşa'daki Liva İdare Meclisi’ne gönderilerek onay alınıordu. ${ }^{43}$

masrafinın belediyece karşılanması kararlaştııılmıştı. Bk. KKTC Millî Arşiv ve Araştırma Dairesi, Kara Kaph Vakfiye Defteri, s. 127, hüküm no: 65. Bununla birlikte bu tarihte Lefkoşa'da İstanbul örneğinde bir belediye teşkilatı bulunduğu şüphelidir. 


\section{Mağusa ve Baf Belediyeleri}

Mağusa'da belediye teşkilatı 1868 yllında kurulmuştur. 9 Şaban 1285 (25 Kasım 1868) tarihli kayda göre "üç re's İslâm ve üç re's Hristiyandan belediye meclisi teşkill" olunmuş ve durum Lefkoşa idare meclisine bildirilmişti. ${ }^{44}$ Belediye Meclisi seçimlerinin 3 Recep 1285 (26 Ekim 1868) tarihinden önce yapıldığı anlaşlıyor. Çünkü 26 Ekim 1868 tarihinde Mağusa Belediye Başkanı Zühdü Efendi'ydi. ${ }^{45}$

Baf kazasında da belediye teşkilatı 1868 yllında kurulmuştur. Baf'ta "Daire-i Belediye Meclisi” kurulması 28 Rebilahir 1285 (18 Ağustos 1868) tarihinde Lefkoşa'dan talep edilmiştir. ${ }^{46}$ Yaklaşık 1 ay sonra, 3 Cemaziyelahir 1285 (21 Eylül 1868) belediye meclisi seçimleri tamamlanmıs,, "aza, sandık emini ve kâtibin" istihdam edilebilmesi için Lefkoşa'dan onay istenilmişti. ${ }^{47}$ Bununla birlikte Baf kazasında belediyenin kurulması ve faaliyete geçmesinin kolay olmadığı anlaşılmaktadır. 7 Recep 1285 (24 Ekim 1868) tarihli olup Baf'tan Lefkoşa'ya yazılan bir yazıya göre "daire-i belediye meclisi azasmnn" toplanacağı ve müzakerede bulunacağı bir oda yoktu. Bu nedenle bir oda kiralanmasının mı yoksa "müstakil bir" yerin inşasının mı daha uygun olduğu Lefkoşa'ya sorulmuştur. ${ }^{48}$ Bu soruya 16 Recep 1285 (2 Kasım 1868) tarihli bir yazıyla cevap verilmiş ve belediye meclisi üyelerinin kullanması için "çarşıda bir mahal"in kiralanmasının uygun olduğu belirtilmiştir. ${ }^{49}$ Baf Belediyesi'nin ilk kâtibinin Ramazan Efendi olduğu ve 1869 yılı Ocak ayında görevinden ayrıldığı anlaşılıyor. Çünkü Baf'tan Lefkoşa'ya gönderilen 8 Şevvâl 1285 (22 Ocak 1869) tarihli bir yazıda Emin Efendi'nin "belediye meclisi kitabetine" tayin edildiği bildirilirken gurre-i Zilkade 1285 (13 Şubat 1869) tarihli bir başka yazıyla da belediye meclisi kâtibi Ramazan Efendi'nin muhasebesinin görüldüğü ve hazırlanan muhasebe defterinin Lefkoşa'ya gönderildiği belirtilmektedir. ${ }^{50}$ 1868 yılında Baf'ta oluşturulan belediye heyeti (kâtip, üye, sandık emini ve azalar) yaklaşık 1 yl görev yaptıktan sonra istifa etmiştir. Baf Kaymakamlığı'ndan Lefkoşa'ya gönderilen 21 Cemaziyelahir 1286 (28 Eylül 1869) tarihli bir yazıda belediye meclisi kâtibinin, sandık emininin ve azalıktan istifa edenlerin istifa mek-

\footnotetext{
44 BOA, TŞR.KB.d., No: 2, s. 40.

45 BOA, TŞR.KB.d., No: 2, s. 45.

46 BOA, TŞR.KB.d., No: 10, s. 4.

47 BOA, TŞR.KB.d., No: 10, s. 4.

48 BOA, TŞR.KB.d., No: 10, s. 39.

49 BOA, TŞR.KB.d., No: 10, s. 5.

50 BOA, TŞR.KB.d., No: 10, s. 38.
} 
tuplarının Lefkoşa'ya gönderildiği belirtilmektedir. ${ }^{51}$ Baf Kaymakamlı̆g bir hafta kadar sonra da, 26 Cemaziyelahir 1286 (3 Ekim 1869) tarihli yazısı ekinde "belediye meclisinin bidayet-i teşkilinden şimdiye kadar vuku bulan hasılat ve masarifâtm mübeyyin" defteri Lefkoşa'ya göndermiştir. ${ }^{52}$ İstifa olayının Eylül 1868 başında gerçekleştiği tahmin olunabilir. Çünkü Lefkoşa'dan Baf Kaymakamlığı'na yazılan 6 Cemaziyelahir 1286 (13 Eylül 1869) tarihli yazıda belediye dairesine ait işlerin şimdilik mevcut kâtipler tarafindan (muhtemelen idare meclisi veya deavi meclisi kâtipleri kastediliyor) görülmesi ve belediye gelirlerinin de mal sandığına alınarak başka bir defter tutulmaması istenilmiştir. ${ }^{53}$

\section{Girne ve Limasol (Leymosun) Belediyeleri}

Girne'de belediye teşkilatı kurulması 1868 yılında Lefkoşa'dan talep edilmiş ise de belediyenin ancak 1870 yılında kurulabildiği anlaşılıyor. Lefkoşa'dan Girne'ye gönderilen 28 Rebiülahir 1285 (18 Ağustos 1868) tarihli bir yazı ile "daire-i belediye meclisinin" oluşturulması istenilmiştir. ${ }^{54}$ Bu yazıya ancak Mart 1870 tarihinde cevap verilmiştir. 18 Zilhicce 1286 (21 Mart 1870) tarihli cevabî yazıya göre belediye meclisi için "ï̧̧er nefer azann icrâ-yn memuriyetleri" (muhtemelen 3 İslam ve 3 Hristiyan azadan oluşan 6 kişilik bir belediye meclisi) için Lefkoşa'dan onay talep edilmiştir. ${ }^{55} 1870$ yllında Girne'de belediye meclisinin kurulduğu ve üye seçiminin tamamlandığı anlaşılıyorsa da Girne Kaymakamlığı'nın Lefkoşa'ya gönderdiği 20 Haziran 1871 tarihli yazı belediye meclisinin içinde bulunduğu sıkıntıları yansıtmaktadır. Yazıya göre "daire-i belediye meclisinin umûr- tahririye ve hesâbiyesini idare ve rüyet edecek" kimse yoktu, belediye reisi ile belediye meclisi üyeleri "okuyup yazmak" bilmiyorlardı ve aylı uygun bir maaşla bir "kâtibin tedârik ve istihdamına" izin verilmesi talep ediliyordu. Lefkoşa İdare Meclisi aylık elli kuruş maaşla "bir nefer kâtibin tayin" ve istihdamı için onay vermiştir. Söz konusu maaş Girne Belediyesi gelirlerinden ödenecekti. ${ }^{56}$

51 BOA, TŞR.KB.d., No: 10, s. 36.

52 BOA, TŞR.KB.d., No: 10, s. 35.

53 BOA, TŞR.KB.d., No: 10, s. 7.

54 BOA, TŞR.KB.d., No: 10, s. 16.

55 BOA, TŞR.KB.d., No: 10, s. 28.

56 BOA, TŞR.KB.d., No: 30, s.33. İlgili yazı Samani tarafindan "1871 tarihinde Girne Kazası Belediye Meclisinin hesaplarn tutacak Sandık Emini henüz istihdam edilmemistir. Meclis başkan ve üyeleri de okuyup yazma bilmediklerinden, uygun bir maaşla bir kâtibin istihdam edilmesi gereklilĭgi, Girne Kaymakamh̆̆ğ tarafindan Kibrns İdare Meclisi’ne bildirilmiştir" şeklinde özetlenmiştir. Bk. Samani, "Tanzimat Döneminde Kıbrıs’ta Modern Belediyeciliğin Başlangıcı ve Lefkoşa Belediyesi”, s. 600. 
Kıbrıs'ın bir diğer kaza merkezi olan Leymosun'da da belediye teşkilatı 1868 y1lında kurulmuştur. Lefkoşa'dan Leymosun Kaymakamlı̆̆ı'na gönderilen 13 Safer 1285 (5 Haziran 1868) tarihli bir yazıda, Leymosun'da henüz belediye teşkilatının kurulmadığının haber alındığı, bu durumun nizamname ile bu konuda yazılan yazıya aykırı bulunduğu ve sorumluluğun bedelinin ağır olacağının açık olduğu ifade edilmiştir. Yazının devamında yukarıda sayılan nedenlerden dolayı Leymosun'a yeniden bir te'kid (üsteleme/uyarı) yazısı gönderme zorunluluğunun doğduğu belirtilmiştir. İlgili yazıda ayrıca yeni bir yazıya gerek duyulmadan nizamına uygun olarak hemen belediye teşkilatının kurulması, üye ve başkan seçiminin yapılması ve seçilenlerin isimlerinin derhal Lefkoşa'ya bildirilmesi emrediliyordu. ${ }^{57} \mathrm{Bu}$ uyarı üzerine 13 gün gibi kısa bir süre içinde Leymosun'da belediye seçimlerinin yapılarak üye ve başkanın isimlerinin Lefkoşa'ya bildirildiği anlaşılmaktadır. Yine Lefkoşa'dan Leymosun'a yazılan 1 Rebiülahir 1285 (22 Temmuz 1868) tarihli yazıda belediye seçimlerinin yapıldığı, 6 kişinin üye seçildiği, fakat kazada Hristiyanların da bulunması ve Hristiyan ihtiyar meclisi üyelerinin girişimi üzerine belediye meclisi için 2 tane de Hristiyan üyenin seçildiği haberinin Lefkoşa'ya ulaştığı ifade edilmektedir. Seçilen Hristiyan üyeler Dimistoni Solomonidi ve Yorgi Simyonidi idi. Seçim işlemi tamamlandıktan sonra durum Lefkoşa'ya 26 Safer 1285 (18 Haziran 1868) tarihli bir yazıyla Leymosun Kaymakamlığınca bildirilmiş ve belediye üyelerinin toplanarak işlerini yapabilmeleri için bir yer kiralanıp kiralanmaması ile yapılması gerekli harcamalar için nasıl bir yol izlenmesi gerektiği sorulmuştur. Lefkoşa'dan verilen cevapta, üyelerin hükûmet konağındaki uygun bir odada toplanmalarının yeterli olduğu, bu nedenle yeni bir yere ve masrafa ihtiyaç olmadığı belirtilmiştir. ${ }^{58} \mathrm{Bu}$ yazı belediyelerin gelir kaynağını açıklaması yönüyle de ayrı bir öneme sahiptir. Çünkü söz konusu yazıya göre, belediyenin çeşitli masrafları için gerekli para "narhdan ziyade erzak ve esya fürûht eden kesândan ber mûcib-i kanun istihsal olunacak cezâ-y nakdiden ve tahrir-i emlak" sayım ve yazımı sona erdikten sonra "ita olunacak kontrato harcından ve bir de tezyinât-ı belediyeye tahsis olunacak mebâliğden" sağlanacaktı. Kısacası belediye gelirleri narhdan fazla satış yapanlara verilecek para cezalarından, emlak yazımı tamamlandıktan sonra emlak sahiplerine verilecek tapu belgelerinden ve ne olduğu açıklanmayan "tezyinât-ı belediye"den ibaret olacaktı. Bir başka deyişle belediye çok az bir gelire sahip olacaktı.

Leymosun Kaymakamlığı konuyla ilgili olarak Lefkoşa’ya 21 Recep 1285

BOA, A.d., Gömlek No: 827, (s.y., dijital çekim numarası: 82). 
(7 Kasım 1868) tarihli bir yazı göndermiştir. Bu yazıda Belediye Meclisi kâtipliğine aylık 200 kuruş maaşla Şükrü Efendi’nin tayin edildiği, Belediye Başkan muavinliğine yine aylık 200 kuruş maaşla Dimitraki Rosidi’nin tayin edildiği belirtilerek uygulamaya geçilmesi için onay istenmekte ve Vilayet Nizamnamesi gereğince tayini gereken müfettişin de Lefkoşa'dan tayini talep olunmaktaydı. Lefkoşa'dan verilen 29 Recep 1285 (15 Kasım 1868) tarihli cevapta Şükrü Efendi ile Dimitraki Rosidi'nin tayinlerinin onaylandığı, bahsi geçen maaşların belediye gelirlerinden ödenmesinin uygun olduğu, vilayet nizamnamesi bir müfettiş tayinini gerekli görüyorsa da maaşının olmaması nedeniyle şimdilik müfettiş tayinine gerek olmadığ1, bu konunun ileride icabına bakılacağı Leymosun'a bildirilmişti. ${ }^{59}$

Yukarıda verilen bilgiler ortaya koymaktadır ki, Kıbrıs'ta İstanbul örneğinde modern belediye teşkilatı kurulmaya 1868 yılında başlandığı ve ilk olarak Lefkoşa'da sonra da Larnaka'da bu teşkilatın kurulduğu anlaşılmaktadır. Çünkü Larnaka'dan Lefkoşa'ya yazılan 7 Safer 1285 (30 Mayıs 1868) tarihli bir yazıda belediye meclisine "düvel-i ecnebiye tebalarndan" üye tayini için izin istenilmiş, ama 7 Ekim 1868 tarihine gelindiğinde bu talebe herhangi bir cevap alınamamışt1. ${ }^{60}$ Fakat bu arada seçimler yapılmış ve 17 Ağustos 1868 tarihinde Mehmet Ali Bey’in Belediye Başkanı olarak tayin onayı Lefkoşa'dan talep edilmişti. Belediye teşkilatı kurulması için Baf ve Girne'ye Lefkoşa'dan gönderilen yazı 18 Ağustos 1868 tarihlidir. Yukarıda anlatıldığı üzere, Mağusa'da bu tarihlerde belediye teşkilatının kurulmuş olması Baf, Girne ve Mağusa’ya 28 Rebiülahir 1285 (18 Ağustos 1868) ${ }^{61}$ tarihinde Lefkoşa'dan talimat gönderildiği izlenimini uyandırmaktadır. Kısacası Kıbrıs'ta, İstanbul örneğinde, modern belediye örgütlenmesinin başlangıcı 1868 yılıdır. Bu gelişmeyi 4 Temmuz 1867 tarihli Vilayâtta Devâir-i Belediye Meclislerinin Vezaif-i Umumiyyesi Hakkında Talimat'in bir sonucu olarak değerlendirmek yerinde olacaktır.

\section{İlk Belediyelerin Gelir Kaynakları ve Masrafları}

1867 tarihli Vilâyâtta Belediye Meclislerinin Suret-i Tertibi ve Memurlannın Vezâifi Hakkında Talimat ile Vilayâtta Devâir-i Belediye Meclislerinin Vezâif-i Umûmiyyesi Hakkında Talimat ${ }^{62}$ isimli hukuki düzenlemeler belediyelerin gelir kayanakları hakkında bazı

59 BOA, A.d., Gömlek No: 827, (s.y., dijital çekim numarası: 189).

60 BOA, TŞR.KB.d., No: 2, s. 3,9.

61 Baf ve Girne'ye bu tarihte Lefkoşa'dan yazı gönderildiği açıktır. Mağusa için böyle bir yazıya rastlanmamış ise de belediye meclisinin oluşturulması ve başkan seçilmesi Mağusa'da bu tarihlerde gerçekleştiği için Baf ve Girne’ye gönderilen yazının Mağusa’ya da gönderildiği düşünülebilir. 
bilgiler vermiştir. Vilâyâtta Belediye Meclislerinin Suret-i Tertibi ve Memurlarmmn Vezâifi Hakkında Talimat'ın 5. bendine göre, belediye idare meclislerinin yavaş yavaş yeterli gelir kaynaklarına sahip olması meclisin göstereceği çabaya bağlı olacak ise de belediye meclislerine bazı gelir kaynakları tahsis etmek gerekliydi. Başkent belediye nizamnamesinde belirtildiği gibi başkent binalarından alınan harcın 1/5'i, inşaat ve tamirat gelirleri, emlak yazımı tamamlanan yerlerden alınması planlanan yeni vergiler arasından ayrılacak bir miktar ile başka yollarla bulunacak ve alınan izin sonrası uygulamaya konulacak yeni kararlar belediyenin gelir kaynaklarını oluşturacaktı. Vilayâtta Devâir-i Belediye Meclislerinin Vezâif-i Umûmiyyesi Hakknda Talimat'ın 15. bendine göre ise "narh ile ölçü ve tartı" nedeniyle uygulanacak para cezaları da belediyelere bırakılmıştır. Söz konusu iki talimat belediye meclislerinin gelir kaynaklarını bu şekilde açıklasa da Kıbrıs ile ilgili arşiv belgeleri durumu biraz daha açıklamaya imkân tanımaktadır.

8 Zilhicce 1285 (22 Mart 1869) tarihli bir kayıt Maliye Nezareti tarafindan belediyelere bırakılan gelir kaynaklarından bahsetmektedir. Buna göre, emlâk yazımı tamamlanmış Lefkoşa şehrinde 1283 (1867) yılında kaldırılmış olan "Yevmiye-i Dekâ" kin ve Dellalbaşılı ve Boyahane" vergileri yeniden ihdas edilerek gelirleri belediyeye bırakılacaktı. Aynı şekilde Lefkoşa'da bulunan ancak halkın şikâyet ve rahatsızlığı nedeniyle kısa süre önce kaldırılmış bulunan "Damga ve Tahmishane Rüsûmu”nun da yeniden toplanmaya başlanarak geliri belediyelere tahsis edilecekti. Buna ilave olarak yeniden "ihdas olunan Zebhiyye Rüsûmu" gelirleri de belediye meclislerinin bir diğer gelir kaynağı olacaktı. Son olarak hali hazırda hazine için tahsil olunan "kantar ve kiyâliyye ve hayvan ve bâc-ı bazar rüsûmâtı dahi" Maliye tarafindan belediyelere terk edilecekti. ${ }^{63}$

\section{"Zebhiyye" ve "Dellaliyye" Vergileri}

Kıbrıs'ta belediyelere tahsis edilen "Zebhiyye" ve "Dellaliyye" 1 Eylül 1285 (13 Eylül 1869) tarihinde ayrıntılı olarak belirlenmiştir. Buna göre 6 kaymakamlı merkezinde elde edilen "Zebhiyye" vergisi toplamı 22.950 kuruş, "Dellaliyye" vergisi ise 3.600 kuruş idi. Toplam gelir ise 26.550 kuruşa ulaşıyordu. ${ }^{64}$

sâni, Matbaa-i Amirede Tab‘ Olunmuştur. Sene 1289, s. 491-493; "Vilayâtta Devâir-i Belediye Meclislerinin Vezâif-i Umûmiyyesi Hakkında Talimat”, Düstur, Cüz-i sâni, Matbaa-i Amirede Tab“ Olunmuştur. Sene 1289, s. 493-497.

63 BOA, TŞR.KB.d., No: 38, s. 70.

64 BOA, TŞR.KB.d., No: 38, s. 28. 
Söz konusu belgede Zebhiyye (Kesimhane) vergisinin ayrıntıları da vardır. Başlangıçta adı geçen verginin Sakız adasındaki gibi olması (kesilen kara sığırın her birinden 5 kuruş, koyun ve keçinin her birinden 40'ar para ile kuzu ve oğlağın her birinden 25’er para) önerilmiş ise de söz konusu miktarların Kıbrıs için ağır olacağı düşünülerek yeni bir vergi oranı belirlenmiştir. Buna göre Kıbrıs'ta kesilecek kara sığırın her birinden 5'er kuruş, koyun ve keçinin her birinden 25'er para ve kuzu ve oğlağın her birinden ise 10'ar para vergi alınacaktı. Bahsi geçen vergi belediyelerce "emanet" usulü yöntemiyle tahsil edilecekti. ${ }^{65} 12$ Ağustos 1871 tarihinde kuzu ve oğlak için belirlenen kesim fiyatının, "mevsimin müruru ve kuzu ve oğlaktan eser kalmaması" nedeniyle kuzu ve oğlak mevsimi gelinceye kadar, 10 paradan 25 paraya çıkarılması kararlaştırılmıştır. ${ }^{66}$

Tablo 1: Kıbrıs Kazalarının Zebhiyye ve Dellaliyye Yıllık Gelirleri

\begin{tabular}{|c|c|c|}
\hline $\begin{array}{c}\text { Kaza Merkezi } \\
\text { (Kaymakamlık) }\end{array}$ & $\begin{array}{c}\text { Zebhiyye (Kesimhane) } \\
\text { Vergisi (Kuruş) }\end{array}$ & $\begin{array}{c}\text { Dellaliyye Vergisi } \\
\text { (Kuruş) }\end{array}$ \\
\hline Lefkoşa & 6.500 & 500 \\
\hline Tuzla & 6.000 & 1.500 \\
\hline Leymosun & 3.500 & 300 \\
\hline Baf & 1.250 & 500 \\
\hline Girne & 4.500 & 300 \\
\hline Mağusa & 1.200 & - \\
\hline Toplam & 22.950 & 3.600 \\
\hline
\end{tabular}

Dellaliyye vergisi ise "rüsûm-ı mezbûre münâdi marifetiyle satılan emlâk ve akar ve eșyann kiymet-i mukarreresinden binde yiğirmi kuruş" şeklinde alınacak ve tahsil olunan paranın yarısı münadiye/dellala ve diğer yarısı da belediye sandığına gelir olarak kaydedilecekti. ${ }^{67}$

BOA, TŞR.KB.d., No: 38, s. 69. İlgili defterin 28. Sayfasında kara sığır için 1 kuruş önerilmiş ise de 69. Sayfada verilen miktar 5 kuruştur.

66 BOA, TŞR.KB.d., No: 30, s. 31.

67 BOA, TŞR.KB.d., No: 38, s. 69. 


\section{"Kantar" Rüsûmu, "Kiyaliye" (Kilecilik) Rüsûmu ve "Hayvan Rüsûmu"}

25 Temmuz 1870 tarihli bir yazıya göre Kıbrıs'ta geliri belediyelere tahsis edilen 3 gelir kalemi daha vardı. ${ }^{68}$ Bunlardan biri olan ancak miktarı verilmeyen Kantar Rüsûmu "tarife-i matbua-i cedide ahkâmına" uygun şekilde tahsis olunacakt1. "Kilecilik" vergisi "kaza ve kurâdan derûn-ı şehr ve kasabâta nakl ile" satılan "hınta ve şair ve burçak misüllü hububâtın" tartılması sırasinda satandan "beher kilede iki ve müsterisinden" dahi iki para, Leymosun kazasinda ise 5 para, olarak tahsil edilecekti. "Hayvan" vergisi ise "şehir ve kasabalarda ve pazar ve panayır yerlerinde" satılan hayvanların "kıymetinden kuruşta bir para" olarak hesaplanacakt1. ${ }^{69}$

\section{"Bâc-1 Bazar" Rüsûmu}

Tuzla ve Leymosun kazalarındaki belediyeler için ayrıca bir de "Bâc-ı Bazar" vergisi tahsis edilmişti. Tuzla kazasını oluşturan Tuzla ve İskele kasabalarında kurulan pazar yerlerinde "kaza ve kurâdan gelen dakik ve kömür ve sebze ve taze üzüm ve sirkenin" her bir yükünden 10 'ar para, "tatlı ve ekşi portakal ve kuru üzüm ve revgan-ı zeytin" her bir yükünden 20'şer para, "nebâtîrin" her bir klyyesinden ve "sahtiyanın" her bir tanesinden 2'şer para ve "siyah hamm" her bir yükünden 2'şer para, "zeyt"in (?) beher yükünden 6'şar, "tahta görün 70 ve (....) ve ziftin" her bir yükünden 40'ar para ve "pekmezin" her yükünden 30 para belediye için alınacaktı.

Leymosun kazası için de benzer bir liste yapılmıştır. Buna göre Limasol'da kurulan pazar yerlerinde "karadan gelen dakik ve anason ve badem ve bakla ve bögrülce ve badadez (patates) ve sisam ve soğan ve kömür ve findık ve zift ve revgan-ı zeyt ve kuru üzüm ve pekmez ve pasdall ve yerli keresteden ve kaba yerli hasırn" her bir yükünden 10'ar para, "duhanı" (her bir yükünden?) 40 para, hamrın beher yükünden 2 para ve arakın her bir yükünden 5, "canavarn" (domuz) her birinden 40, "penbenin beher Kibrns kantarndan ve yapağının" her bir yükünden 20'şer para, "taze bakla ve zerdali ve sairenin" her bir yükünden "aynen bir kıyye hesabınca" belediye için tahsilat yaplacaktı.

68 BOA, TŞR.KB.d., No: 38, s. 70.

69 BOA, TŞR.KB.d., No: 38, s. 69.

70 Gör: Ocakta yakılan büyük kütüklerin yanmasını kolaylaştırmak için altına konulan destek.

71 Okunamadi. 


\section{Para Cezaları}

Belediyelerin gelir kaynaklarından bir başkası "narh ile ölçü ve tartı" nedeniyle uygulanacak para cezalarıydı. Bununla birlikte 1873 yılında bu konuya açıklık kazandırmak gereği duyulmuştur. 8 Mart 1873 tarihli olan maliyeden Kıbrıs Mutasarrıflı̆̆ı'na gönderilen bir yazıya göre "esnaf eksikcikleriyle" belediyeler tarafindan konulmuş nizama aykırı hâl ve hareketlerde bulunanlardan belediye meclisi kararıyla belirli bir miktarda "ceza-yı nakdî" tahsiline izin verilmişti. Ancak belediye daireleri dışında olarak mahkeme ve başka meclislerin kararıyla tahsil edilen para cezaları belediyelere ait olmayacaktı. Bu tür "ceza-yı nakdı"ler merkezî hazineye aitti ve ancak merkezî hazine tarafindan hapishanelerin tamiri ile ilgili masraflar için kullanılmaktaydı. Durum böyle iken bazı yerlerde bu ayrıma önem verilmediği için çeşitli karışıklıklar ortaya çıkmıştır. Maliyeye göre, maliye tarafindan belediyelere terk edilen gelir kaynakları belediyelerin göreceği işler için yeterlidir

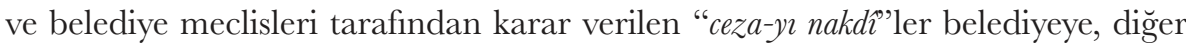
meclis ve mahkemeler tarafindan verilen "ceza-yı nakdı"ler ise merkezî hazineye aittir. İlgili yazı, belediyelerin bu tür ceza gelirlerinin hesap defterlerini tutmakla mükellef olduklarını hatırlatarak sona erdirilmiştir. ${ }^{72}$

\section{"Emanet"ten "İltizam"a: Lefkoşa'da "Zebhiyye" Rüsûmunun Tahsili}

1869 yllında alınan kararla Kıbrıs'taki Zebhiyye vergisinin "emanet" yöntemiyle tahsil edilmesi kararlaştırılmıştı. Bununla birlikte yaklaşık 2 yıl sonra Lefkoşa Belediye Meclisi'nin söz konusu vergiyi tahsilde "iltizam" usulünü kabul ettiği görülmektedir. Belediye meclisi kararına göre "Lefkoşa Zebhiyye Rüsumu” 1 Eylül 1287-31 Ağustos 1288 (13 Eylül 1871-12 Eylül 1872) tarihlerini kapsayacak şekilde bir ylllı̆̆ına iltizama verilmiştir. Nazlı oğlu Mehmet Ağa, kardeşi Ahmet Ağa'nın kefil olmasıyla yıllık 7.300 kuruş bedel ile Lefkoşa Belediyesi kesimhane vergisini iltizamına almışır. Belediyenin kararında ayrıca söz konusu miktarın önceki yılınkinden yüksek olduğu ve adı geçen verginin "maktu'an ihalesi"nin "emaneten idaresinden hayvrl"

72 KKTC Milli Arşiv ve Araştırma Dairesi, Mutasarnflk Defterleri, No:5, s. 37. Tebligatın tarihi "9 Muharrem 1289 ve 24 Şubat 1288” olarak yazılmış ise de defterdeki diğer belgelerin tarihi ile 24 Şubat 1288 tarihinin miladi karşılığı dikkate alındığında, aslında kasdedilen tarihin "9 Muharrem 1290 ve 24 Şubat 1288” olduğu ortaya çıkmaktadır. Rumi 24 Şubat 1288 tarihinin karşılığı da "8

Mart 1873"tür. Türk Tarih Kurumu tarih çevirme sitesinde 9 Muharrem 1290 tarihinin miladi karşlığı 9 Mart 1873 ve 25 Şubat 1288 olarak hesaplanmaktadır. Günümüzde yapılan bu tür çevirilerde 1 günlük fark çıkabileceğinden bu çalışmada metindeki Rumi "24 Şubat 1288” tarihi esas alındı. Bu tarihin miladi karşılığı ise 8 Mart 1873'tür. 
olacağı bu şekilde anlaşılmıştır. Belediyenin söz konusu kararı, Lefkoşa’daki sancak meclisi tarafindan 9 Aralık 1871 tarihinde onaylanmıştır.

\section{Azledilen Lefkoşa Belediye Başkanları ve İstifa Eden Meclis Üyeleri}

1874 yılı sonunda Lefkoşa Belediye başkanı Kâmil Efendi idi. Kâmil Efendi başkanlık yanında "kitabet" ve "sandık eminliğì" görevlerini de üstlenmişti. Bununla birlikte Lefkoşa'daki Sancak İdare Meclisi tarafindan Kıbrıs Mutasarrıfina bir yazı gönderilmiştir. İlgili yazıya göre Kâmil Efendi "b̂-hakkın ifâ-yı vazife-i memuriyete gayr-ı muktedir" olduktan başka Lefkoşa'nın "tenzifât ve ıslahatiyla beraber erzak ve es'arnnn dahi revâyic-i mutedile ve lâylkada füruht ve tedarikince nezâret ve dikkat-i lâzıme icrâsı" belediye başkanlarının görev ve sorumluluklarından olmasına rağmen Kâmil Efendi bu konularla ilgilenmemiştir. Belediye borçlarının ödenmeden kalması da ileride olumsuz sonuçlara neden olacağından Kâmil Efendi’nin azli ve yerine daha önce bu görevde başarısı ispatlanmış olan Karpaz Nahiyesi eski Müdürü İbrahim Efendi'nin tayin edilerek "kitabet ve sandık emaneti" görevlerinin de kendisine verilmesi mutasarrıflı̆ga arz edilmiştir. Bu görevler karşılığında İbrahim Efendi’ye aylık 500 kuruş maaş tahsisi de istenilmiş ve talep 24 Aralık 1874 tarihinde onaylanmiştır. ${ }^{73}$

İbrahim Efendi’nin çok uzun süre bu görevleri ifa etmediği anlaşılmaktadır. Çünkü yaklaşık bir yıl sonraki benzer bir yazı belediye başkanı, sandık emini ve kâtip olarak Ahmet Nazif Efendi'den bahsetmektedir. 10 Şubat 1876 tarihli söz konusu yazı hemen hemen yukarıdaki ile aynıdır ve Ahmet Nazif Efendi'nin azli talep edilmektedir. Ilgili yazı Ahmet Nazif Efendi'nin yerine "sadakat-i iffet ve istikametle ve kanunen mahdud ve muayyen olan vezâifin enva'r aksamma vakıf olan Kibris asâkir-i zabtiyesi" eski Tabur Ağası Naim Efendi'nin 13 Şubat 1876 tarihinden itibaren geçerli olmak üzere tayin edilmesi talebiyle sona eriyordu. Kayıtta dikkati çeken önemli noktalardan birisi de Naim Efendi'nin "maaş-ı muhassasıyla tayin" edilmiş olmasıdır. ${ }^{74}$ Belediye başkanlarına maaş tahsisi öngörülmediğine göre, buradaki "maaş-ı muhassas" ifadesini "sandık eminliği ve kâtiplik maaşı" olarak değerlendirmek gerekmektedir.

1876 yll ortalarında yaşanan bir başka olay ise Lefkoşa Belediye Meclisi üyelerinden üçünün istifa etmesidir. Hüseyin Efendi, Mihail Bodono ve Hacı Antoni

BOA, TŞR.KB.d., No: 30, s. 105. 
"Ağalar" üyelikten istifa etmiş olup istifa nedenleri ilgili kayıtta açıklanmamışır. Boşalan üyelikler için yeniden seçim yapılmış ve Dellalbaşı Ahmet, Bazirgan Yanko Hristofidi ve Hristofaki Milo "Ağalar" seçimde gerekli oyu alarak Lefkoşa Belediye Meclisi üyesi olmuşlar ve üyelikleri 16 Temmuz 1876 tarihinde Lefkoşa İdare meclisi tarafindan onaylanmıştır. ${ }^{75}$

\section{Belediye Başkanlarının Maaşı Meselesi}

Hasan Samani'nin belirttiğine göre, belediye meclisini oluşturacak altı üye "emlak ve arazi sahipleri" arasından seçilecek ve bu kişiler maaşsız olarak hizmet edeceklerdi. Belediye başkanı ise "mevcut memurlar" arasından atanacak, belediyede istihdam olunacak "kâtip ve sandık emini" maaşlı olacak ama maaşları 500'er kuruşu geçmeyecekti. ${ }^{76} \mathrm{Bu}$ ifadeler belediye başkanları için ayrı bir maaş tahsisinin öngörülmediğini göstermektedir ki, mevcut uygulamalar da bu yönde olmuştur. Yukarıdaki kısımda belirtildiği üzere 1874-1876 yıllarında Lefkoşa belediye başkanlığı yapanlara ayrıca bir de başkanlık maaşı ödenmemişti. Bununla birlikte, söz konusu tarihler arasında Lefkoşa belediye başkanı olarak ismi geçen Kâmil Efendi, İbrahim Efendi, Ahmet Nazif Efendi ve Naim Efendi üç görevi (başkanlık, sandık eminliği ve kâtiplik) birden üstlenmişlerdi. "Sandik eminliği ve kâtiplik" görevleri ücretli olduğundan, bu uygulama aslında belediye başkanları için bir çeşit gelir temin etme yolu olarak belirlenmiş olmalıdır. Çünkü normalde maaşsız olan belediye başkanları söz konusu fiili durumla maaş almaya hak kazanıyorlardı.

14 Kasım 1877 tarihli bir belge de belediye başkanlarının normalde maaşsız oluşlarını teyit etmektedir. Kayda göre, Leymosun Kaymakamlığı'ndan Lefkoşa Mutasarrıflı̆gı'na 14 Kasım 1877 tarihli bir yazı ulaşmış ve ilgili yazıda Leymosun Belediye Başkanı Fethi Efendi'ye maaş tahsisi talep edilmiştir. 9 Ocak 1878 tarihinde konuyu görüşen Lefkoşa İdare Meclisi, Leymosun Belediye Başkanı Fethi Efendi’nin hizmet ve gayretlerinin takdire şayan olduğu ve bu nedenle de yeterli miktarda maaş ve ödül tahsisine layık bulunduğu sonucuna varmışt. Böyle olmakla birlikte, "ne çare ki belediye rüesasina maaş tahsisine nizamât-ı mevzu'a gayr-i müsaid ve Meclis-i Mebusan'dan tanzim olunan beledî kanun layihalan" hükümleri de gayri müsaid olduğundan Lefkoşa İdare Meclisi talebin reddine karar vermek durumunda kalmiştır.

75 BOA, TŞR.KB.d., No: 31, s. 59.

76 Samani, “Tanzimat Döneminde Kıbrıs’ta Modern Belediyeciliğin Başlangıcı ve Lefkoşa Belediyesi", s. 598-599. 


\section{Belediyelerin Harcamaları ve Hesaplarının Denetlenmesi}

Kıbrıs'ta kurulan belediyelerin çok zengin gelir kaynakları olmasa da bir miktar paranın söz konusu yeni kurumun hazinesini oluşturduğu görülmektedir. Bu azlığa rağmen doğrudan belediyelerle alakası olmayan durumlar için belediyeler tarafindan harcama yapılmıştır. Kıbrıs adası H.1284 (M.1867-68)-H.1286 (M.1869-70) ylları arasında Cezayir-i Bahri Sefid Vilayeti'ne bağlı bulunan bir sancak idi. ${ }^{77}$ Kıbrıs'ta modern belediyelerin kurulması bu yıllara rastlamaktadır. Bu dönemde vilayet merkezinde oluşturulan "Meclis-i Umûmî”ye Kıbrıs'tan 6 kişi (her kazadan bir kişi) katılmıştı. Bu kişilerin masraflarını oluşturan toplam 3.500 kuruşun ilgili kazaların belediye sandıklarından (Lefkoşa 450, Tuzla 1.000, Leymosun 750, Baf 500, Girne 400 ve Mağusa 400) ödenmesine 16 Ocak 1871 tarihinde Lefkoşa'daki İdare meclisi tarafından karar verilmiştir. ${ }^{78}$ İstanbul'dan Kıbrıs Mutasarrıflığına yazılan 13 Haziran 1872 tarihli bir yazıda ise "aşı ameliyatmi icra etmek için taşraya gönderilecek" doktorlara ve diğer görevlilere verilecek "maaş ile bir mahalden diğer bir mahale" giderken kiralayacakları hayvanlarn ücreti ve diğer gerekli harcamaların belediye sandıklarından karşılanmasının uygun olacağı bildirilmiştir. ${ }^{79}$

Bazı harcamalar ise doğrudan belediyelerin görev alanı ile ilgiliydi. 1875 yılında Lefkoşa Belediyesi "belediyeye müracaat eden" ya da herhangi bir nedenle belediyeye davet olunan bazı Hristiyanlar Türkçe bilmediklerinden bir tercüman istihdamına karar vermişti. Söz konusu tercüman hem tercümanlık yapacak hem de belediyeye gelen Türkçe olmayan evrakı Türkçeye tercüme edecekti. Belediye Meclisi kararına göre bu iş için en uygun aday "otuz beş seneden beri Devlet-i Aliyye'de istihdam olunarak şimdiki halde" boşta ve işe hazır durumda bulunan Pavlaki idi. Belediye Meclisi'nin 27 Temmuz 1875 tarihinden başlamak ve aylık 150 kuruş maaşla Pavlaki'nin tercüman olarak işe alınması kararı Lefkoşa İdare Meclisi tarafindan uygun bulunmuştur. ${ }^{80} 1876$ yllında ise Lefkoşa'da yol tamiri için istihdam olunan Mihail Efendi'nin 33 günlük çalışması karşlığında ödenmesi

77 Kıbrıs Mutasarrıfi Sait Paşa'ya yazılan 20 Rebiülahir 1287 (20 Eylül 1870) tarihli yazıda Kıbrıs'ın Cezayir-i Bahr-i Sefid Vilâyeti’nden ayrılarak müstakil Mutasarrıflık olduğu bildirilmiştir. Bk. Dionyssiou, The Implement of the Tanzimat Reforms in Cyprus (1839-1878), s. 221-223.

BOA, TŞR.KB.d., No: 30, s. 46

KKTC Millî Arşiv ve Araştırma Dairesi, Mutasarnflk Defterleri, No. 5, s. 13.

BOA, TŞR.KB.d., No: 30, s. 94. 
gereken 500 kuruş 30 paranın belediyece ödenmesi onaylanmıştır. ${ }^{81}$ Aynı yılda Lefkoşa su yollarının tamiri gerekmiş, bu tamirat için 966 kuruş harcanmış ve masrafın temini için kurulan özel bir komisyon marifetiyle söz konusu tamirattan istifade eden ev sahiplerden para toplanmıştı. Bununla birlikte, Belediye Meclisi yine de bu konuda İdare Meclisi'ne bir yazı yazarak masrafin toplanan paradan mı yoksa belediye sandığında bulunan paradan mı karşılanmasının uygun olacağını sormuştur. İdare Meclisi mevcut paranın şehir içindeki başka masraflar için gerekli olduğunu belirterek bahsi geçen tamirat için ise o amaçla toplanmış paranın kullanılmasına karar vermiştir. ${ }^{82}$

1867 tarihli Vilâyâtta Belediye Meclislerinin Suret-i Tertibi ve Memurlarnnn Vezâifi Hakkında Talimat' 1 beşinci bendinde açıklandığı üzere belediyeler "ne miktar vâridât ve hasilat olur ise" günlük olarak ilgili defterlere tarih ve ismiyle yazmak ve her ay sonunda belediye sandığının hesabını görüp kayıt altına almakla mükellef idiler. ${ }^{83}$ Bununla birlikte, belediyelerin kuruluşu sürecinde yaşanan kimi sorunlara benzer sorunların belediyelerin gelir-gider hesaplarının düzenlenmesi konusunda da yaşandığı anlaşılmaktadır. Maliye Nezâreti'nden Kıbrıs Mutasarrıflı̆̆’na gönderilen 29 Mayıs 1871 tarihli bir yazı, Kıbrıs'taki belediyelerin Rumî 1285 (13 Mart 186912 Mart 1870) senesi "irâd ve masraf defterlerinin henïz" gönderilmemiş olduğunu belirterek bir an önce ilgili defterlerin hazırlanarak gönderilmesini istiyordu. ${ }^{84}$

Anlaşıldığına göre, söz konusu gelir-gider defterleri hazırlanarak kısa süre içinde gönderilmiştir. Ancak bunun üzerine Maliye'den Kıbrıs Mutasarrıflı̆̆ı'na ilginç bir cevabi yazı gelmiş̧ir. Yazıya göre, Kıbrıs mutasarrıflı̆̆ 2 Temmuz 1871 tarihli yazısı ekinde 1285 (13 Mart 1869-12 Mart 1870) mali y1l gelir-gider hesaplarını özet bir hesap pusulass şeklinde göndermiş ve 1286 (13 Mart 1870-12 Mart 1871) mali yılı gelir-gider hesaplarının da kısa süre içinde gönderileceğini bildirmiştir. Buna göre, Kıbrıs belediyeleri 1869-1870 mali yılında 36.389 kuruş gelir elde etmiş ve 22.041 kuruş da harcama yapmıştı. Mevcut nakit miktarı ise 14.348 kuruş 17 paraydı.

Bu özet hesap bildirimi maliyeyi tatmin etmemiş ve söz konusu hesaplamanın ayrıntılı olarak yapılıp gönderilmesi talep edilmiştir. Yazıya göre, Kıbrıs Muta-

81 BOA, TŞR.KB.d., No: 31, s. 34.

82 BOA, TŞR.KB.d., No: 31, s. 82

83 "Vilâyâtta Beledive Meclislerinin Suret-i Tertibi ve Memurlarnnn Vezâifi Hakkında Talimat", Düstur, Cüz-i sâni, Matbaa-i Amirede Tab‘ Olunmuştur. Sene 1289, s. 492.

84 KKTC Millî Arşiv ve Araştırma Dairesi, Mutasarnflık Defterleri, No. 11. 
sarrıflı̆̆ı bahsi geçen 36.389 kuruşun hangi gelir kaynaklarından sağlandığını ve harcandığı belirtilen 22.041 kuruşun ise hangi masraflar için harcandığını açıkça izah edecekti. Bunlar yapılmadığı takdirde "belediye muhasebelerinin tamamlanmış" sayılmayacă̆ı vurgulanmıştır. Aslında hazinenin öğrenmek istediği iki temel nokta vardi:

1. Hazine tarafindan belediyelere terk olunan ve hazinece verilen özel talimata uygun olarak yeni ihdas edilen vergilerin "idare ve ihalesinde bedel ve hasılatı neye baliğ" olmuştu?

2. Vilayâtın İdare-i Umûmiye Nizamnamesinin 126. Maddesine göre belediye meclisinin tahsilinde yetkili olduğu "sair şeylerden ne miktar hasılat" meydana gelmişti?

Sonuç olarak yukarıdaki iki soruya cevap olacak şekilde hesap dökümü talep ediliyordu. Hazine bu bilgilerden hareketle genel gelir kaynaklarından olup da belediyelere tahsis olunan vergilerin merkezî hazine kayıtları ile uyum içinde olup olmadığını da bilmek istiyordu. Bu nedenle Kıbrıs'tan gönderilecek hesap dökümünde; 1. Kıbrıs'ta belediyelerin kuruluş yılı olan 1284 (1868) senesi "bedelâtı ve mukabilinde dahi" yapılan harcamaların ayrıntıları açıkça gösterilecekti.

2. 1285 (1869-1870) ve 1286 (1870-1871) mali yılı muhasebe defterleri de o şekilde düzenlenip gönderilecekti.

3. 1286 (1870-1871) mali yılı muhasebe defteri hazırlanırken 1285 senesi muhasebe defterindeki gelir esas alınacaktı.

Maliye son olarak ise büyük miktardaki harcamaların sorulmadan yapılmamasını özellikle talep ediyor ve yukarıdaki noktalara dikkat edilmesini istiyordu.

13 Haziran 1872 tarihli olan ve Lefkoşa Mutasarrıflı̆̆ı'na gönderilen bir başka yazı da yine belediye muhasebe defterleriyle ilgilidir. Yazıya göre, "belediye dairelerinin beher sene miktar-ı varidât ve masarifâtın" içeren "birer muhasebe defterinin" düzenlenerek gönderilmesi gerekli iken "Kibrns ceziresindeki devâirin müddet-i malume muhasebe defterleri henüz" gelmemişti. Ayrıca daha önce gelen defterlerin içeriği hakkında talep olunan ayrıntılı "cevabı da henüz gönderilmemistir." Bu durum mali işlemlerin düzenini aksattığından "defâtir-i matlubenin hemen ve bundan sonrasının dahi sene be sene" düzenlenerek gönderilmesi ve merkezce sorulan sorulara ayrıntılı cevaplar veril- 
mesi Lefkoşa'ya bildiriliyordu. Mutasarrıflık, merkezden gelen bu yazıyı 11 Temmuz 1872 tarihinde belediye başkanlığına havale etmiştir. ${ }^{85}$

\section{Osmanlı Yönetiminin İngiliz İdaresine Belediye Mirası}

1878 yılı ortalarında Kıbrıs'ın yönetimi İngilizlere devredildiği zaman Kıbrıs'taki Ingiliz valisi adanın idari, sosyal ve ekonomik durumunu belirten bir rapor hazırlamışır. 1880 tarihli söz konusu rapor Baf ve Girne'de belediye meclisinin varliğından bahsetmemekle birlikte Leymosun, Mağusa, Tuzla ve Lefkoşa'da belediye idaresinin bulunduğunu ifade etmektedir. Rapora göre, özellikle umumî tuvaletler, yiyecek maddelerinin denetimi, ölçülerin kontrolü gibi konularda Limasol'da gün geçtikçe iyi çalışan bir belediyeye olan ihtiyaç artmaktaydı. ${ }^{86}$ Mağusa ve Maraş kasabalarını kapsayan Mağusa Belediyesi "hâlâ emekleme durumunda/bebeklik çağinda" bulunurken $^{87}$ Larnaka Belediyesinin çalışmaları ise ihtiyaca cevap vermiyordu. Kanalizasyon/lağım konusundaki çalışmalar yetersizdi, sığırlar sahilde kesiliyordu, leş yiyen sayısız köpek mevcuttu, kasabada aydınlatma sistemi yoktu, dar ve dolambaçlı yollar görünmez tehlikelerle doluydu, umumî tuvalet ve belediye zabıtası mevcut değildi. ${ }^{88}$ Lefkoşa'daki belediye çalıştığı görülen tek belediye idi. ${ }^{89}$

\section{Sonuç}

Kıbrıs'ta modern belediye teşkilatının kurulması için ilk girişim 1682 yılında Kıbrıs Mutasarrıfı Ziya Paşa'nın girişimi ile başlamış ise de asıl gelişme 1867 yılındaki Vilayâtta Devâir-i Belediye Meclislerinin Vezâif-i Umûmiyyesi Hakknda Talimat' $\mathrm{n}$ bir sonucu olarak yaşanmıştır. Söz konusu talimatın bir sonucu olarak Kıbrıs'ta modern belediyeler 1868 yılı başından itibaren kurulmaya başlanmış ve bu süreç Lefkoşa, Tuzla, Baf, Mağusa ve Leymosun kazalarında 1868 yılında tamamlanmıştır. Girne'de ise belediye teşkilatının kurulması ancak 1870 yılında mümkün olmuştur. Incelenen dönemde gayrimüslim belediye başkanına rastlanmazken gayrimüslim belediye meclisi üyelerinin var olduğu tespit edilmiştir. 1871 yllına gelindiğinde ise tüm eksiklik ve sorunlarına rağmen Kıbrıs'ta modern belediye teşkilatının kuruluşu üç yıl içinde tamamlanmış görünmektedir. s. 41.

KKTG Millî Arşiv ve Araştırma Dairesi, Cyprus Reports, s. 85.

KKTC Millî Arşiv ve Araştırma Dairesi, Mutasarrnflk Defterleri, No: 5.

KKTC Millî Arşiv ve Araştırma Dairesi, Cyprus Reports, 1880,1881, 1882, (Basım yılı ve yeri yok),

KKTC Millî Arşiv ve Araştırma Dairesi, Cyprus Reports, s. 192-193.

KKTC Millî Arşiv ve Araştırma Dairesi, Cyprus Reports, s. 244-245. 
Belediyeler için önem arzeden meselelerden birisi yeni kurumun gelir kaynakları meselesidir. Bu bağlamda, belediyelere gelir temin etmek için daha önce kaldırılmış olan bazı vergiler yeniden tahsil edilmeye başlanmıştır. "Zebhiyye", "Dellaliyye", "Kantar", "Kilecilik", "Hayvan" ve "Bac-ı Bazar", "Damga" ve "Tahmishane" vergileri ile tartı ve ölçü nedeniyle ya da belediyelerin uygulamaya koyduğu usullere aykırı hareket edenlerden alınacak "ceza-yı nakdi", belediyelerin başlıca gelir kaynakları olarak belirlenmiştir. Vergilerin tahsilinde "emanet" usulünün kullanılması kabul edilmiş ise de kısa süre sonra "iltizam" usulü uygulanmaya başlanmıştır.

Kıbrıs'ta belediyelerin kuruluş ve çalışma aşamalarında sorunlar yaşandığı gibi gelir ve gider hesaplarının özenli bir şekilde tutulmasında da problemler olduğu ortaya çıkmaktadır. Belediye başkanlarının yetersizlikleri sebebiyle görevlerinden alındığı, belediye başkanlarının başkanlık, kâtiplik ve muhasebecilik işlerini de yürüttüğü görülmektedir. Benzer şekilde yıllık gelir-gider hesaplarının kuruluş süreci içinde istenildiği ölçüde ayrıntılı olarak tutulmamış olmasının belediyelerden beklenen hizmetlerin yerine getirilmesini zorlaştırdığı söylenebilir.

Bütün idari ve mali eksiklik ve sorunlara rağmen idari modernleşme sürecinin önemli bir parçasını oluşturan modern belediyelerin 1868 yılında Kıbrıs'ta kurulduğu görülmektedir. Kıbrıs bu konuda İmparatorluğun birçok yerinden daha erken bir tarihte bu kuruma sahip olmuştur. Bununla birlikte ada yönetimi 1878 yılında İngilizlere devredildiği zaman 1868 yılında kurulmuş olan belediyeler tam anlamıyla çalışan birer kamu kurumu olmaktan oldukça uzakta bulunuyorlardı. 


\section{KAYNAKLAR}

\section{Arşiv Belgeleri}

\section{Gumhurbaşkanlığı Devlet Arşivleri Başkanlığı, Osmanlı Arşivi BOA, İstanbul}

Kıbrıs Mutasarrıflı̆̆ Defterleri (TŞR.KB.d.).

No:2, 10, 30, 31, 38,40.

Meclis-i Vala Riyaseti Defterleri (MVL.).

Dosya No: 788, Gömlek No: 65.

Divan-1 Hümayun Bâb-1 Asafi Defterleri

A.d., Gömlek No: 827.

\section{Kuzey Kıbrıs Türk Gumhuriyeti Milli Arşiv ve Araştırma Dairesi (Girne)}

Mutasarrıflık Defterleri, No:5.

Mutasarrıflık Defterleri, No.11.

KKTG Millî Arşiv ve Araştırma Dairesi, Cyprus Reports, 1880,1881, 1882.

\section{Basılı Kaynaklar}

Düstur, Def’a-i Saniye Olarak Matbaa-i Amirede Tab’ ve Temsil Kılınmışdır. Fi gurre-i Zilhicce sene 1282.

Düstur, Cüz-i sâni, Matbaa-i Amirede Tab’ Olunmuşdur, Sene 1289.

\section{Araştırma ve İnceleme Eserler}

Çadırcı, Musa, Tanzimat Döneminde Anadolu Kentlerinin Sosyal ve Ekonomik Yapısı, Türk Tarih Kurumu Basımevi, Ankara 1997.

Dionyssiou, George A., The Implementation of the Tanzimat Reforms in Cyprus (18391878), MAM (The House of Cyprus \& Cypriologial Publications), Nicosia 2009

Ertürk, Meral, Kibrns'ta Belediyeler ve Türk Belediye Başkanlan I: Lefkoşa İlçesi, Cumhuriyet Gazetesi Matbaası, Lefkoşa y.y.

Hill, George, A History of Cyprus, v. 4, Cambridge University Press, Cambridge 1952. 
Jennings, Ronald. C., "Lefkoşa", Kubrus, (Derleme ve Çeviri: Mehmet Akif Erdoğru), Galeri Kültür Yayınları, Lefkoşa 2010.

Katsiaounis, Rolandis, Labour, Society and Politics in Cyprus, Cyprus Research Center, Nicosia 1996.

Kyriazes, N., Kypriaka Hronika, 12 (1936), s. 208-213.

Kyrris, Costas P., History of Cyprus, Nicosles Publishing House, Nicosia 1985.

Luke, Harry, Cyprus under the Turks, Oxford University Press, London 1921.

Miralay, Mustafa Miralay, Belediyelerimiz: Kibrn'ta Belediyelerin Dünü ve Bugünü, (?), Lefkoşa 1984.

Oktay, Tarkan, "Osmanlı Döneminde Modern Belediye Kurumunun Doğuşu ve Gelişimi”, (Eds) Erol Özvar ve Arif Bilgin, Selçukludan Cumhuriyete Şehir Yönetimi, Türk Dünyası Belediyeler Birliği Yayını, İstanbul 2008, s. 393-396.

Ortayl, İlber, "Belediye", TDV İslam Ansiklopedisi, C 5, Türkiye Diyanet Vakfi Yayınları, İstanbul 1992, s. 398-402.

Ortaylı, Ilber, Türkiye Teşkilat ve İdare Tarihi, Gedit Neşriyat, Ankara 2012.

Sakellarios, Athanasios, Ta Kypriaka: Htoi Geographia, Istoria kai Glossa tis Nisou Kyprou

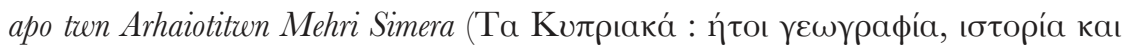

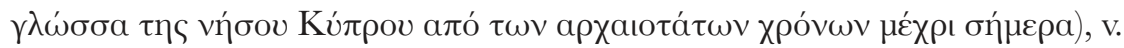
1, (Athens: 1890).

Samani, Hasan, Tanzimat Deurinde Kibris (1839-1876), Hacettepe Üniversitesi Sosyal Bilimler Enstitüsü, (Yayımlanmamış Doktora Tezi), Ankara 2006.

Samani, Hasan, "Tanzimat Döneminde Kıbrıs'ta Modern Belediyeciliğin Başlangicı ve Lefkoşa Belediyesi”, Belleten, 82/294 (2018), s. 588-626.

Seyitdanlığlu, Mehmet, Tanzimat Döneminde Modern Belediyeciliğin Doğuşu, Türkiye İş Bankası Kültür Yayınları, İstanbul 2010. 
